\title{
WAKENING A SLEEPING METAPHOR: A NEW INTERPRETATION OF MALACHI 1:11
}

\author{
Åke Viberg
}

\section{Summary}

From the early history of the Christian church and onwards, interpreters have suggested that Malachi 1:11 presents a universalism, i.e, that the surrounding nations of post-exilic Judah actually worshipped $Y H W H$ as the one true God by their sacrifices. In this article I propose that neither this solution, nor any other previously proposed solution does sufficient justice to Malachi 1:11. Instead, I propose that we focus on how the author uses metaphorical language to strengthen his argument. In doing so, however, the author creates a new metaphor that continues to challenge the understanding of the reader.

\section{Introduction}

Interpreters have considered Malachi 1:11 one of the most difficult texts in the OT, both exegetically and theologically. A number of solutions have been offered, but none has achieved the status of a scholarly consensus. ${ }^{1}$ In this article, I will present

\footnotetext{
1'See J.T. Marshall, 'The Theology of Malachi', ET 7 (1895) 74-5; R. MartinAchard, Israël et les nations. La perspective missionnaire de l'Ancien Testament (Cahiers Théologiques 42; Neuchâtel: Delachaux, 1959); M. Rehm, 'Das Opfer der Völker nach Mal 1,11' in H. Groß and F. Mußner (eds.), Lex tua veritas (Festschrift H. Junker; Trier: Paulinus, 1961) 193-208; J. Swetnam, 'Malachi 1,11: An Interpretation', CBQ 31 (1969) 200-9, J.G. Baldwin, 'Malachi 1:11 and the Worship of the Nations in the Old Testament', TynB 23 (1972) 117-24; R.L. Smith, Micah-Malachi (WBC 32; Word Books: Waco, 1984) 312-6; B. Glazier-McDonald, Malachi. The Divine Messenger (SBLDS 98; Atlanta: Scholars Press, 1987) 55-61); R.J. Coggins, Haggai, Zechariah, Malachi (OT Guides; Sheffield: JSOT, 1987) 77-8; P.A. Verhoef, The Books of Haggai and Malachi (NICOT; Grand Rapids: Eerdmans, 1987) 222-32; S. Hidal, 'Magnum est nomen meum in gentibus' Israel och Hellas. Studier kring Gamla Testamentet och dess verkningshistoria (Religio 27; Lund: Teologiska institutionen, 1988) 55-62; G.P. Hugenberger, Marriage as a
} 
the problem and then briefly describe various solutions. I will examine various proposed interpretations and then argue that a more satisfying interpretation is yielded by close attention to the metaphorical nature of the statement 'My name is great among the nations' in v. 11a and its elaboration in v. 11b, 'in every place incense is offered to my name.'

\section{The Problem of Malachi 1:11}

In Malachi 1:6-9 the priests are criticised for neglecting their duties, and in v. 10 the author describes $Y H W H$ 's reaction to this. Then, as a contrast with vv. 6-9, the author states as follows in v. 11:2

11a kî mimmizrah-ร̌emeš wĕ adměbồô gādôl š̌mî baggôyim

11b âmŭqțār mŭggās lišmî ûminhâ țěhôrâa
For from the rising of the sun to its setting my name is great among the nations,

and in every place incense is offered to my name, a pure offering;

Covenant: A Study of Biblical Law and Ethics Governing Marriage Developed from the Perspective of Malachi (VTS 52; Leiden: Brill, 1994) 37-9.

2Some consider vv. 11-14 to be a later addition to the original text; e.g., $\mathrm{K}$. Elliger, Das Buch der zwölf kleinen Propheten II (ATD 25/2; Vandenhoek \& Ruprecht: Göttingen, 1949) 198; R. Rendtorff, 'Maleachibuch' RGG ${ }^{3} 4.628$; H. Utzschneider, Künder oder Schreiber? Eine These zum Problem der 'Schriftprophetie' auf Grund von Maleachi 1,6-2,9 (BEATAJ 19; Peter Lang: Frankfurt am Main, 1989) 40,84. The arguments put forward in favour of this view have not convinced scholars in general, however. This view is usually based on the conclusion that Mal. 1:11 expresses a universalism that does not fit in with the particularism otherwise found in the book of Malachi. Since we will show below that this is not the proper interpretation of Mal. 1:11, the view that it is secondary becomes unnecessary; $c f$. Hugenberger, Marriage, 39, n. 53.

${ }^{3}$ The two hophal participles mŭqtăr and mŭggăs have been seen as problematic in earlier analyses, mainly due to the fact that they are hapax legomena. I take mŭqtār as the subject and mŭggās as the predicate; so Swetnam, 'Malachi 1,11', 201; Glazier-McDonald, Malachi, 57; Verhoef, Malachi, 225. For two participles forming a relationship such as this, see Is. 
11c kî̀-gādôl šĕmî baggôyim

'āmar $Y H W H$ șĕbā'ôt for my name is great among the nations, says the Lord of hosts.

The obvious problem in Malachi 1:11 is that YHWH appears to proclaim that the cultic practices of the nations are pleasing to him. But how can this be, considering the exclusivism that characterises the worship of YHWH in the OT? Is this a moment of profound insight on behalf of the prophet, whose vision extends beyond the narrowness of national religion, or is he inadvertently overstating his case by a slip of the tongue? Several solutions have been offered in earlier attempts to understand this verse. ${ }^{5}$ We can divide these earlier attempts

21:2. The participle mŭqtār can mean 'smoke', but this does not harmonise well with the following expression 'pure offering', which clearly refers to actual sacrifices. The participle mŭqtär can also refer to burned offerings in general; so Rehm, 'Das Opfer', 196 ('was man in Rauch aufgehen läßt'), and Glazier-McDonald, Malachi, 57. However, because a similar nominal form with the prefix $m$ - occurs in Ex. 30:1 (miqtārr, 'altar of incense'), I would prefer a more specific meaning 'incense offering'; so Baldwin, 'Malachi 1:11', 58 and W. Rudolph, Haggai - Sacharja 1-8 - Sacharja 9-14 Maleachi (KAT 13.4; Gütersloh: Gütersloher Verlagshaus, 1976) 257, 259. There is an example of a hophal participle in Ps. 69:3 (mo'ðmād) which functions as a substantive, 'a place to stand on'; see HALAT II, 581. There is therefore no reason to follow Th. Chary (Aggée-Zacharie-Malachie [Sources Bibliques; J. Gabalda; Paris, 1969] 241-2) in revocalising mŭqtār into miqtār.

4I take the phrase aminha těhôră, 'and a pure offering', as attributive to the subject mŭqtär, describing the character of the offering made. The conjunction in âminha is then explicative; see B.K. Waltke and M. O'Connor, An Introduction to Biblical Hebrew Syntax, (Winona Lake: Eisenbrauns, 1990) 648-9.

In the following, I will not deal with the application of this verse in relation to the Eucharist, a view occurring as early as Didache. 14.3, and later, for example, in Justin Martyr's Dialogue with Trypho, 117. For this view, see B. Mariani, 'De Sacrificio a Malachia praedicto', Anton 9 (34) 193242; 361-82; 451-74; Th. Chary, Les prophètes et le culte a partir de l'exil (Bibliothèque de théologie série III, Théologie Biblique 3; Tournai: Desclée \& Cie, 1955) 183-6; H.S. Frank, 'Maleachi 1,10ff' in der frühen Väterdeutung. Ein Beitrag zur Opferterminologie und Opfer-verständnis 
into three categories, depending on whether they interpret Malachi 1:11 as referring to the present, or as referring to the future, or understand it figuratively as hyperbole.

\section{Malachi 1:11 as Referring to the Present}

\section{Sacrifices offered by the nations}

The most popularly held view of Malachi 1:11 has been that it is the neighbouring nations who perform the sacrifices that are pleasing to YHWH. 6 This view is based on the argument that monotheistic trends in thinking enjoyed a significant amount of influence in the days of Malachi. According to this view, Malachi 1:11 asserts that the growing tendency toward monotheistic belief among the nations is tantamount to belief in the one true God. As Johannes Lindblom, a proponent of this view, put it in his study of OT prophecy:

I adhere to the view that the reference here is to the monotheistic tendency of pagan religions during the Persian period. Worship of only one god, of the most high god, of the god of heaven was widespread. This tendency influenced the author of Malachi and he identified the worship of this god with the worship of $\mathrm{YHWH}$, the god of Israel, regarded as the god of the universe.?

This is sometimes related to the church fathers' idea of a logos spermatikos, the belief that there is but one God and that any

Fornberg, 'Malachi 1:11 in Jewish and Christian Tradition', Jewish-Christian Dialogue and Biblical Exegesis (Studia Missionalia Upsaliensia 47; Uppsala, 1988) $47-74$.

6See Verhoef, Malachi, 225-9 for further literature and a more detailed criticism, and also Hugenberger, Marriage, 38-9.

7J. Lindblom, Prophecy in Ancient Israel (Oxford: Blackwell, 1962) 406. See also Marshall, 'The Theology of Malachi', ET 7 (1895) 75; F. Horst, 'Nahum bis Maleachi', Die Zwölf kleinen Propheten (HAT 14; 3rd. ed.; J.C.B. Mohr: Tübingen, 1964) 267. 
sacrifice offered to him with good intentions is received with approbation. 8

The obvious strength of this view is that it agrees with the apparently universal scope of the text. The all-embracing expression, 'from the rising of the sun to its setting', is unequivocal in its universality. ${ }^{9}$ This phrase is also found in Psalms 50:1 and 113:3 and in Isaiah 45:6 and 59:19, though the wording is slightly different in the last case. It denotes the allencompassing nature of the rule of $\mathrm{YHWH}$. Furthermore, that YHWH's name is said to be great probably refers to some form of cultic worship. When the priests have profaned their sacrificial duties at the altar, they have in effect despised YHWH's name (Mal. 1:6, 7). In v. 11 the greatness of YHWH's name is probably linked in a similar way to the offering of incense. The text proceeds to call these incense offerings 'pure offerings', emphasising that these cultic practices were acceptable to YHWH. Indeed, this is the only text in the OT that uses $t h r$ or $t h r h$ concerning offerings. 10 Otherwise $t h r$ or $t h r h$

${ }^{8}$ Rudolph (Haggai, 263) seems to propose a modified version of this view, namely that what is at stake is not so much an ideology held by the author, as some concrete experience, which is not accessible to us. Rudolph is at the same time aware of the limitations of his view, especially in the light of the condemnation of Edom in 1:3f. and the prohibition of intermarriage with foreign women in 2:11f. For the latter, see B. Glazier-McDonald, 'Intermarriage, Divorce, and the bat-'él nēkār: Insights Into Mal 2:10-16', JBL 106 (1987) 603-11. See also E. Jacob (Theology of the Old Testament [London: Hodder \& Stoughton, 1958] 67, 222), who combines this view with the eschatological interpretation, described below. See also $n$. 3 above.

${ }^{9}$ This expression should be taken in a geographical rather than a chronological sense, as is borne out by the following locative marker, 'in every place'. The phrase in v. 11a was probably a standard expression, since it is known from one of the Amarna letters, 288:5-7, sent by the king of Jerusalem to the Pharaoh: "The king, my lord, has established his name from the rising of the sun to its setting'; see J.A. Knudzon, Die El-AmarnaTafeln (Vorderasiatische Bibliothek 2/1-2; Hinrichs: Leipzig, 1907-15). It also occurs in the Phoenician inscription from Karatepe, see J.C.L. Gibson, Textbook of Syrian Semitic Inscriptions. Vol. 3. Phoenician Inscriptions (Oxford: Clarendon, 1982) 46-7.

10See Baldwin, 'Malachi 1:11', 124. This is apparently overlooked by Verhoef, Malachi, 225. 
refers to cultic purity in general without any connection to sacrificial acts. 11

It is difficult, however, to harmonise this view with the general tendencies of OT thought, and particularly with the content of books that stem from exilic or post-exilic times. The text often cited by proponents of this view as a corroborative parallel is Jonah 1:14, where non-Israelite sailors pray to YHWH.12 However, the parallel is not convincing since the sailors initially pray to their own gods (1:5). It is only after Jonah tells them of the God he worships, the maker of sea and dry land (1:9) that their thoughts turn to YHWH. When the storm finally ends, the seamen recognise Jonah's God as the true God and worship him accordingly (1:16). ${ }^{13}$ There are also indications from within the book of Malachi itself that such a universalistic view can hardly be correct. Malachi 1:2-5 pronounces YHWH's judgement upon Edom and, according to 3:4, YHWH will one day restore the offering of sacrifices as in the days of old and these will be pleasing to him. According to $2: 11$, it is an abomination for men to take wives who worship foreign gods. This practice is liable to severe punishment (2:12). The presence of such assertions in the Book of Malachi make it improbable that 1:11 should be taken as accepting the validity of the monotheistic beliefs held by the neighbouring nations.

The specific formulation of $\mathrm{v} .11$ renders this view even more improbable. The hiphil of $n g \breve{s}$, 'bring forth', is not commonly used for presenting sacrifices. Of the eight occurrences of the term with this meaning, four are in Malachi $(1: 7,8,12 ; 3: 3)$. It is never used to refer to the presentation of offerings of incense, for which the hiphil of $q \bar{a} a \mathrm{rab}$ is the proper term. In addition, the use of $t h r$ in this text is distinctive. In other places it is used of cultic purity (Lv. 10:10; Dt. 12:15; Jb.

\footnotetext{
${ }^{11}$ See H. Ringgren, 'thr' in TDOT, 5. 291-4.

12So J. Blenkinsopp, A History of Prophecy in Israel (Philadelphia: Westminster, 1983) 271. Rudolph (Haggai, 263) seems to have neglected the importance of the conversion, both of the seamen in Jon. 1 and the town of Nineveh in Jon. 3. It is not their worship of their own gods which is accepted as pleasing by $\mathrm{YHWH}$, but their conversion from heathen practises to the worship of YHWH.

${ }^{13}$ See J.M. Sasson, Jonah (AB; New York: Doubleday, 1990) 138.
} 
14:4); only in Malachi 1:11 does thr refer to the purity of sacrifices. This unusual use of terminology indicates that the author is trying to convey something other than a portrayal of the presentation of acceptable sacrifices. I will return to this argument below.

Therefore, the universalistic interpretation of Malachi 1:11 is inadequate in view of the statements that are made in the text. The universalistic view appears merely to provide readers with an argument for a universalism they have already accepted. The following proposals have been put forward to provide for a more exclusive view of who might actually be envisioned as performing the sacrifices.

\section{Sacrifices offered by Diaspora Jews}

One solution is to simply maintain the traditional view that it is Jews who are envisioned as performing these sacrifices. However, since the text clearly states that the sacrifices are performed among the nations, those offering the sacrifices must be Jews in the Diaspora. ${ }^{14}$ Such a view does indeed find some corroboration in the existence of Jewish temples in Elephantine and possibly also in Leontopolis during this period. ${ }^{15}$

Nevertheless, there is nothing whatsoever in the text that supports this view. Instead, the view that the sacrifices are not only offered among the nations but are presented by them as well is clearly implied by the text. The whole point of this passage relies on maintaining a contrast between the priests and the nations. ${ }^{16}$ Any idea of the sacrifices being offered by

\footnotetext{
${ }^{14}$ So H. Schultz, Old Testament Theology. The Religion of Revelation in its PreChristian Stage of Development, Vol. 1 (T.\&T. Clark: Edinburgh, 1909) 425: J.M.P. Smith, 'Malachi', A Critical and Exegetical Commentary on Haggai, Zechariah, Malachi and Jonah (ICC; T.\&T. Clark: Edinburgh, 1912) 32; A. von Bulmerincq, Der Prophet Maleachi (Tartu: J.G. Krüger, 1926-32) 129-31; Swetnam, 'Malachi 1,11', 207; Utzschneider, Künder, 84-6. Justin Martyr notes in his Dialogue with Trypho, 117, how popular this view was among the Jews of his day. This interpretation is also reflected in the Targum and was the view of Rashi.

${ }^{15}$ For Leontopolis, see Josephus Ant. 13.3.1 §65-8. It was founded by the refugee Onias IV under the reign of Antiochus V, Eupator (164-162).

${ }^{16}$ See the contrast between the rejected $m n h h$ in v. 10 and the pure $m n h h h$ in v. 11 .
} 
Jews in the Diaspora does not harmonise with the fundamental thematic direction of the text.

\section{Sacrifices offered by Jewish proselytes}

Some scholars have held that those performing the sacrifices are Jewish proselytes of gentile extraction. ${ }^{17}$ This seems to be a compromise between seeing the nations themselves or Jews in the Diaspora as the active party. The sacrifices are understood figuratively as referring to prayer, as in Psalm 51:18-21 and above all in Psalm 141:2: 'Let my prayer be counted as incense before you, and the lifting up of my hands as an evening sacrifice.'18

However, the same fundamental criticism should be brought against this view as was brought against the former view. There is simply nothing in the text to imply a distinction between the those making sacrifice on the one hand and the nations on the other.

17So T.C. Vriezen, 'How to Understand Malachi 1:11' in J.I. Cook (ed.), Grace Upon Grace (Festschrift L.J. Kuyper; Eerdmans: Grand Rapids, 1975) 134: Blenkinsopp, A History, 240-1, 272-3. See Glazier-McDonald, Malachi, 58 for further references.

${ }^{18}$ This was the understanding of the Targum; see K.J. Cathcart, and R.P. Gordon, The Targum of the Minor Prophets (The Aramaic Bible 14; Edinburgh: T.\&T. Clark, 1989) 230-1: 'For from the rising of the sun even to its setting my name is great among the nations, and on every occasion when you fulfil my will I hear your prayer and my great name is hallowed because of you, and your prayer is like a pure offering before me, for my name is great among the nations, says the Lord of hosts.' Regarding the reading of the Targum, see also R.P. Gordon, 'Terra Sancta and the Territorial Doctrine of the Targum to the Prophets' in J.A. Emerton and S.C. Reif (eds.), Interpreting the Hebrew Bible (Festschrift E.I.J. Rosenthal; CUP: Cambridge, 1982) 121-2: and idem, 'Targumic Parallels to Acts XIII 18 and Didache XIV 3', NovT 16 (1974) 287-9, where he also discusses the reference to Mal. 1:11 in Didache. 14:3. The interpretation of sacrifice in the spiritualised sense of prayer can be found in the Dead Sea Scrolls (e.g., 1QS 9:4f, 10:14), as well as in the New Testament (e.g., Heb. 13:15; 1 Pet. 2:5). 


\section{Malachi 1:11 as Referring to the Future}

The various interpretations presented so far have all assumed that the sacrifices in question are envisioned as taking place in the present. Since these interpretations have all been found to be unconvincing, the alternative of seeing the sacrifices as taking place in the future, though still taken literally as actual sacrifices, should be considered. ${ }^{19}$ According to this view, the sacrifices will be offered in the eschatological era, when the nations come to know YHWH. This idea is found elsewhere in the OT (Is. 2:1-4; 19:18-23; 25:6-9; 66:23; Mi. 4:1-4; Zc. 8:20-23; Zp. 2:11). The hophal participle muggäs, 'is brought forward', is generally taken as referring to the present, but from a grammatical point of view it can just as easily refer to the future. ${ }^{20}$

However, the main question that must be raised in this connection is: why did the author not take the trouble clearly to portray the events as future if that was his intention? Why did he express his references to the future by means of participles which, as must be admitted, usually express the present? These questions force us to examine the context in search of sufficient evidence that the text has a future reference. However, since the context indicates precisely the opposite, this view appears

${ }^{19}$ So P.M. Schumpp, Das Buch der zwölf Propheten (Herders Bibelkommentar 10/2; Verlag Herder: Freiburg, 1950) 389-90; A. Deissler, 'Malachie', La Sainte Bible: Tome VIII, Les petits prophètes (Letouzey \& Ané: Paris, 1961) 635-7; idem, Zwölf Propheten III: Zefanja, Haggai, Sacharja, Maleachi (Die Neue Echter Bibel: Altes Testament 21; Echter: Würzburg, 1988) 322-3; P.A. Verhoef, 'Some Notes on Malachi 1:11', Biblical Essays (University of Stellenbosch: Stellenbosch, 1966), 169-70; idem, Malachi, 230 (with some reservations); Baldwin, 'Malachi 1:11'; Chary, Les prophètes, 183; idem, Malachie, 245-6; Glazier-McDonald, Malachi, 60-1; Fornberg, 'Malachi 1:11', 50, 67; M.E. Tate, 'Questions for Priests and People in Malachi 1:2-2:16', RevExp 84 (1987) 399; A. Meinhold, 'Maleachi/Maleachibuch', TRE 22 (1992) 8; I. Willi-Plein, Opfer und Kult im alttestamentlichen Israel. Textbefragungen und Zwischenergebnisse (SBS 153; Stuttgart: Katholisches Bibelwerk, 1993) 83; $c f$. also 150-2, Hugenberger, Marriage, 38-9. For further critique of this view see Hidal, 'Magnum est nomen', 57.

20One example of such a case is 2 Sam. 20:21; see Hidal, 'Magnum est nomen', 57. 
unlikely.21 Why would the author contrast the inadequacy of the priests of Malachi's day with the future sacrifices of the nations?22 A closer look at the context will clarify this. The priests are criticised for the inadequacy of their practices in $\mathrm{v}$. 10 , as well as in v. 12 . Verse 11 is therefore the positive counterpart of this negation of priestly practices. The contrast that Malachi seems to be presenting is not between the present and the future, but between the cultic behaviour of the priests and that of the nations. There is no hint whatsoever of a shift in temporal perspective between vv. 10 and 12.23 It is the mere ideological improbability of the actual performance and acceptability of the acts described in v. 11 that has forced some scholars to place these offerings in the future. In Malachi 3 and 4 , by contrast, we find unambiguous references to the future. It is in these later chapters, and not in 1:11, that we should look for the eschatology of the book of Malachi. ${ }^{24}$

If the view that the text refers to the future automatically forces one to see the sacrifices figuratively, the need for such an eschatological interpretation vanishes, since the verse can be interpreted figuratively without recourse to eschatology.

${ }^{21}$ Rudolph, Haggai, 262.

22This point is also made by Smith, Malachi, 31, Swetnam, 'Malachi 1,11', 203, and S.D. Snyman, 'Eschatology in the Book of Malachi', OTE 1 (1988) 72. In another essay ('Antitheses in the Book of Malachi', JNSL [1990] 1738) Snyman has shown the importance of antithesis in understanding the book of Malachi, although he fails to mention the antithesis between the priests and the foreign nations. See also J.A. Fisher, 'Notes on the Literary Form and Message of Malachi', CBQ 34 (1972) 317-8; S.L. McKenzie and H.N. Wallace, 'Covenant Themes in Malachi', CBQ 45 (1983) 563; E. Wendland, 'Linear and Concentric Patterns in Malachi', BT 36 (1985) 110. I fail to see the relevance of Hugenberger's argument that the reminder of Yahweh's purpose of converting the nations would add force to his condemnation of the priestly cult of Jerusalem (Marriage, 39). There is no logical relationship between these two elements. Furthermore, according to Hugenberger, Yahweh's plan for the nations has the temple as its focus. But there is no emphasis whatsoever in Mal. 1:11 on the fact that the nations will come to Jerusalem or the temple.

23So Martin-Achard, Israël, 41.

${ }^{24}$ See Snyman, 'Eschatology', 63-77, who denies any eschatological reference in 1:11. 
The literal interpretations, whether relating to the present or the future, are, therefore, unconvincing. The remaining possibility is understanding v. 11 as portraying the present but in some non-literal, secondary or figurative sense.

\section{Interpreting Malachi 1:11 as Hyperbole}

There are those who prefer not to take v. 11 literally but as a hyperbole. According to this interpretation, the author does not intend to describe the nations as bringing acceptable sacrifices, but as showing a more appropriate dedication and sincerity than the Israelite priests of Malachi's day. The important point to note in this alternative is that something positive is indeed asserted about the nations, namely that they are dedicated and sincere in their religion, and in this respect they serve as an example to Israel, according to the author of Malachi 1:11.25 This alternative suffers from the difficulty of maintaining that the foreign nations are described in such an approving manner, even though this does not imply the rightness of their cultic practices, as did the first alternative. This hyperbolic interpretation, although positive in the sense that it recognises the need to interpret v. 11 figuratively, does not go far enough, in my opinion. A more convincing interpretation would be to understand v. 11 as a metaphorical statement and the most crucial clue to this interpretation can be found in the parallel statement in v. 14.

\footnotetext{
25So Hidal, 'Magnum est nomen', 61; Ringgren, 'thr', 293. According to Ringgren, the expression 'pure offerings' gives 'echoes of the notion of proper intention'. For similar views, see R. Mason, The Books of Haggai, Zechariah, and Malachi (CNEB; Cambridge: CUP, 1977) 144-5; idem, Preaching the Tradition: Homily and Hermeneutics after the Exile (Cambridge: CUP, 1990) 243, 295-6; Martin-Achard, Israël, 41; Vuilleumier, 'Malachie', Aggée, Zacharie, Malachie (Commentaire de l'ancien Testament XIc; Neuchâtel: Delachaux, 1981) 230; J.M. O'Brien, Priest and Levite in Malachi (Atlanta: Scholars Press, 1990) 65. See Smith, Micah-Malachi, 314-5 for further references.
} 


\section{Malachi 1:11 as Metaphor: A New Solution}

The interpretation of a metaphor begins by noting that if we take the expression literally in its context, some sort of incongruity emerges. 26 In the course of reviewing earlier proposals above, we argued that this is clearly the case with Malachi 1:11. The solution to the problem of this incongruity lies in recognising that the author is using the figurative language of metaphor. A basic, yet workable definition of 'Metaphor' is supplied by Soskice: 'Metaphor is that figure of speech whereby we speak about one thing in terms which are seen to be suggestive of another.'27 This notion of a 'suggestion' going in what seems to be the wrong direction is what often makes it hard to interpret a metaphor, and this applies particularly well to Malachi 1:11.

We will begin to unravel the metaphor of Malachi 1:11 by noting the structural similarity between $\mathrm{vv}$. 6-11 and the following unit, vv. 12-14:28

vv. 6-9

6-9: $\quad$ Criticism of priests

10: YHWH's reaction

11: $\quad$ (Introduced by $k \hat{\imath}$ ) vv. 12-14

12-13b: Criticism of priests

13c-14a: YHWH's reaction

14b: Basis for YHWH's

accusations and demands,

(introduced by $k \hat{\imath}$ )

Vv. 6-11 consist of a detailed criticism of the negligent cultic practices of the priests in vv. 6-9, followed by $\mathrm{YHWH}^{\prime}$ s reaction

\footnotetext{
26E.F. Kittay, Metaphor. Its Cognitive Force and Linguistic Structure (Oxford: Clarendon, 1987) 23: 'My claim... is that a unit of metaphor is any unit of discourse in which some conceptual or conversational incongruity emerges.'

27J.M. Soskice, Metaphor and Religious Language (Oxford: Clarendon, 1985) 15.

${ }^{28}$ See Hidal, 'Magnum est nomen', 59-60.
} 
in v. 10 and then v. 11 , introduced with a causal $k \hat{\imath}$, 'because'.29 When we compare this to vv. 12-14, a similar structure can be observed. In vv. 12-13b the priests are criticised in detail, vv. 13c-14a present $Y H W H ' s$ reaction and $v .14 b$ provides the basis for YHWH's accusations and demands with a causal $k \hat{\imath}$, just as in v. 11. The function of v. $14 \mathrm{~b}$ is paralleled in v. 11. Both v. 11 and v. $14 \mathrm{~b}$, then, seem to function as the basis and rationale for the preceding negative pronouncements of $\mathrm{YHWH}$. Given this similarity in function, it is important to compare these two verses in detail.

If we leave out $\mathrm{v} .11$ for the moment and concentrate on v. $14 \mathrm{~b}$, we find another statement that requires a figurative

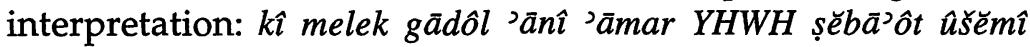
nôrä' baggôyim, 'For I am a great king, says the Lord of hosts, and my name is feared among the nations.' Two things are stated here. First, that YHWH is melek gädôl, 'a great king' (v. $14 \mathrm{b \alpha}$ ) and second that his name is nôra' baggôyim, 'feared among the nations' (v. 14b $\beta$ ). The second statement reiterates the content of the first statement in v. $14 b \alpha$, which would mean that v. 14b refers, although implicitly, to the image of YHWH as a great king over the nations. We can compare this with Ps. 47:3 and 95:3 (see below). It thus becomes apparent that the thought of the all-encompassing dominion of $\mathrm{YHWH}$ in v. 14b functions as the authoritative basis for the earlier demands regarding the cult in vv. 12-14a.

${ }^{29}$ I take the $k \hat{\imath}$ at the beginning of v. 11a as causal, 'because', outlining the basis for the demands that precede. This seems to be the consensus view (e.g., Verhoef, Malachi, 223). However, Utzschneider (Künder, 25, n. 5) considers it impossible to take the $k \hat{\imath}$ as anything other than emphatic, which he uses as an argument for the independence of vv. 11-14 (p. 31), and subsequently its secondary status (p. 40). This causal $k \hat{\imath}$ is found again in $11 c$, which reiterates $11 \mathrm{a}$ in an abbreviated form. Verse $11 \mathrm{a}-\mathrm{c}$ is thereby given a chiastic structure, $a^{1}: b: a^{2}$. It should be noted, however, that the conjunction $k \hat{\imath}$ is probably part of a stereotyped formula, 'because YHWH's name is great among the nations'. This $k \hat{\imath}$ is sometimes taken as adversative, which highlights even more the contrast between the priestly sacrifices in v. 10 and the sacrifices in v. 11; see Swetnam, 'Malachi 1,11', 200 , n. 1. However, normally it is the conjunction we which is used in Malachi for the adversative (1:2 and 1:12). It is interesting that the initial $k \hat{\imath}$ of v. $14 \mathrm{~b}$, a close parallel to v. 11 , is clearly causal, as will be shown below. 
It is important at this stage to note that the expression 'great king' in v. $14 \mathrm{~b} \alpha$ functions metaphorically. Incidentally, this has not presented itself as a problem of the same magnitude as v. 11. The reason for this is that the kingship of YHWH is well known to interpreters as a standard metaphor. There are many points which are worthy of discussion concerning metaphors and how we should interpret them, but I will limit myself here to the important fact that a metaphor should be seen as an analogy drawn between two conceptual domains. ${ }^{30}$ I will call these two domains 'vehicle' and 'topic'. 31 In this case the description 'great king' functions as the vehicle through which we perceive the topic, i.e., YHWH, in a certain way. The conceptual domain of the vehicle is that of being king, whereas the conceptual domain of the topic is $\mathrm{YHWH}$, his acts, character and reactions. What is transferred through the metaphorisation, i.e., the meaning of the metaphor in v. $14 \mathrm{~b} \alpha$, is something like the notion of rule and supremacy, implying authority and dominion. The metaphor evokes a literal meaning, that $\mathrm{YHWH}$ is king, only to replace it with a secondary, non-literal meaning, which in this case is implicit, as is quite often the case. The main reason why the interpretation of this metaphor is still largely transparent to modern readers is that it has become a standard metaphor, which is used repeatedly in the OT. ${ }^{32}$ It is much more difficult to detect and understand a novel or rare metaphor, such as the one which I believe is present in v. 11 .

30See Kittay, Metaphor, 291-2. Kittay uses the expressions 'semantic field' and 'content domain' but it is not necessary for our present purposes to draw such distinctions. The term used here, 'conceptual domain', is meant to include both of Kittay's categories. See also P. Ricoeur, 'The Bible and the Imagination' in H.D. Betz, The Bible as a Document of the University (Chico: Scholars Press, 1981) 66-7, who relates this approach to the notion of intertextuality and also to the interpretation of Jesus' parables: 'Parabolization is the metaphorization of a discourse.'

${ }^{31}$ See P. Cotterell, and M. Turner, Linguistics and Biblical Interpretation (Downers Grove: IVP, 1989) 300, who use 'tenor' in stead of 'topic', which is preferred by Kittay, Metaphor, 26.

32See Kittay, Metaphor, 296-9 for a good treatment of the differences between novel, standard and dead metaphors. See also Soskice, Metaphor, 71-83. 
If we compare vv. $14 \mathrm{~b}$ and 11 , important similarities emerge, and also differences. Verse 11 states twice that YHWH's name is great among the nations, whereas according to v. $14 \mathrm{~b} \mathrm{YHWH}$ is a great king, implicitly over the nations, and the nations fear his name. It would seem that vv. 11 and $14 \mathrm{~b}$ not only have a similar function in relation to their respective contexts, as was argued above, but they also say substantially the same thing, namely that YHWH rules the world with supreme authority. This is made quite clear in v. 14b through the use of the standard metaphor 'YHWH is king'. The same applies to the phrases in v. 11a and v. 11c, though v. 11a is an elaborated version of the metaphor as it occurs in v. 10c. This becomes clearer by looking at the structure of v. 11:

11a kîmimmizrah-šemeš wĕ ad-mĕbô'ô gadôl sermí baggôyim

11b aběkol-māqôm mŭqțār mŭggāš lišmî ûminḥ̂a tẹhôrâa

11c ki-

gadol semi baggóyim

'āmar YHWH șĕbā'ôt

If we concentrate on v. $11 \mathrm{a}$ and c, we find that the phrase gädôl baggoyim, 'great among the nations' is metaphorically related to క̌̌mî, 'my name', a standard metonymy for $\mathrm{YHWH}$, as the vehicle to the topic. The approximate function of the metaphor would then be to express YHWH's world-wide dominion, as is indicated by the structure used to convey the standard metaphor in v. 11a.33 This becomes clear when one analyses the author's use of repetition of v. 11a in v. 11c, where the elaboration of the metaphor included in v. 11a, mimmizrah-šemes wercad-mĕbô'ô, 'For from the rising of the sun to its setting', is

${ }^{33} \mathrm{We}$ could even regard the expression 'among the nations' as an expansion of the basic vehicle 'great'. The basic structure of the metaphor would then be 'YHWH is great', which in turn would be a short form of the metaphor 'YHWH is a great king.' 
left out. The chiastic construction formed by the placement of identical formulations of the metaphor in v. 11a and c places $\mathrm{v}$. $11 \mathrm{~b}$ in the centre, arguing in favour of the view that $\mathrm{v} .11 \mathrm{~b}$ forms the most important element of the construction and constitutes the climax of the whole sentence.

Scholars do not seem to have had any problems understanding the statements in v. 11a and c as metaphorical. The problems have arisen, however, with the author's elaborations of this basic metaphor in v. 11a and b. The elaboration of the metaphor in v. 11a, 'For from the rising of the sun to its setting' has not been the main obstacle in understanding the metaphorical nature of v. 11 and so we will leave it aside here. The heart of the problem lies with the elaboration in v. 11b: ûběkol-māqốm ${ }^{34}$ mŭqțār mŭggā̌s lišmî ûminhâ țěhôrâ, 'in every place incense is offered to my name, a pure offering.' This is the statement that has caused the confusion concerning v. 11 as a whole, as emerged in the review of earlier scholarly interpretations presented above. Indeed, the major difference between vv. 11 and $14 \mathrm{~b}$ is this elaboration in v. $11 \mathrm{~b}$. However, there is no reason in principle why this statement in $v .11 \mathrm{~b}$ should be seen to counter our understanding of the surrounding statements in v. 11a and c, and indeed of v. 11 as a whole, as metaphorical.

When in v. 11b the author states, in a veiled and indirect manner, that the nations offer pure sacrifices that are pleasing to $\mathrm{YHWH}$, he is in fact elaborating on the metaphor in v. 11a and c by further qualifying the description of the vehicle, 'great among the nations'. Verse $11 \mathrm{~b}$ is therefore the answer to the implied question, How is YHWH's name great among the nations? In answering this question in v. 11b, the author uses another metaphor in v. $11 \mathrm{~b}$ to elaborate on the metaphor in $\mathrm{v}$. 11a and c. The topic of this new metaphor in v. 11b, 'my name', is the same as in the metaphor in v. 11a and c, but this time it is

${ }^{34}$ In the expression běkol-mäqôm, 'on every place' mäqôm refers to cultic places (see J. Gamberoni, 'mäqôm' TWAT 4.1113-24), a use which is also found in Phoenician; see R.S. Tomback, A Comparative Semitic Lexicon of the Phoenician and Punic Languages (Scholars Press; Missoula, 1978) 195-6. 
correlated with the new vehicle of pure offerings being brought in every place.

The author has formed the metaphorical sentence in $\mathrm{v}$. 11 on the basis of a standard metaphor, 'YHWH is king', 35 which appears in v. $14 b, 36$ and probably also in v. 5b, yigdal $Y H W H$ mécal ligbul yisrā'el, 'Great is the Lord beyond the borders of Israel.' 37 Such standard metaphors are sometimes called root metaphors, 38 and are especially well suited for generating new metaphors in particular contexts. The cultic use of this metaphor can be found above all in the so-called royal Psalms:

$47: 3$

kî YHWH 'elyôn nôră' melek gädôl ‘al kol-hā’āreș

47:8 kî melek kol-hāāreṣ 'ělōhîm

47:9 mälak 'ělōhîm 'al gôyim 'ělōhîm yäšab ‘al kisse’’ qodsô

95:3 kî̀ 'ēl gādôl YHWH

amelek gãdôl ‘al kol-'ělōhîm
For YHWH Elyon is feared, a great king over all the earth.

For God is king of all the earth.

God rules over the nations;

God sits on his holy throne.

For YHWH is a great God, a great king over all gods.

${ }^{35}$ See M.C.A. Korpel, $A$ Rift in the Clouds. Ugaritic and Hebrew Descriptions of the Divine (UBL 8; Münster: Ugarit-Verlag, 1990) 280. Concerning the epithet gādôl, 'great', he says that it is 'mostly used to express God's royal power, his control over all gods and men'.

36So Swetnam, 'Malachi 1,11', 202.

37See M.Z. Brettler, God is King. Understanding an Israelite Metaphor (JSOTS 76; Sheffield: JSOT, 1987). I prefer to take the composite preposition $m \bar{e}^{\varsigma} a l$ as 'beyond' rather than 'over'.

38For this, see P.A. Porter, Metaphors and Monsters. A Literary-Critical Study of Daniel 7 and 8 (CBOTS 20; Lund: Almqvist \& Wiksell International, 1983) 39-40; T.N.D. Mettinger, In Search of God. The Meaning and Message of the Everlasting Names (Philadelphia: Fortress, 1988) 52, 215, n.1. Both scholars apply this idea to concepts of YHWH in the OT, Porter to the concept of shepherd and Mettinger to that of king. G.B. Caird, The Language and Imagery of the Bible (London: Duckworth, 1980) 177, lists the relationship king/subject as one of the five most basic metaphors which describes YHWH's relationship with his worshippers. 
96:4 kî gãdôl YHWH âmëhullal

$m \breve{e}^{\prime} \bar{o}$ nôrä' hû' 'al kol-'ělōhîm
For YHWH is great, and greatly to be praised; he is feared above all gods.

The similarity between these Psalms and the language used in Malachi 1:11 makes it likely that the cultic situation has generated the basic form of the latter metaphorical expressions. Since the metaphor in v. 11 concerns the sacrificial system, and since the particular terminology used in forming the metaphor in v. 11 has its origin and probably its most well-known use in the Israelite cult, this conclusion becomes all the more likely.

The author of Malachi 1:11 has elaborated upon the standard metaphor ' $\mathrm{YHWH}$ is king' to suit his particular context, which is his polemic against the negligent priests. In such a case the metaphor takes on a new and innovative aspect, and hence becomes more difficult to understand. We could say that the author has wakened a slumbering metaphor and transformed it into a new and challenging one, while at the same time hindering the readers' capacity to comprehend. This is why, in constructing a novel metaphor, the difficult path must be taken between the unique and challenging on the one hand and the incomprehensible on the other. This tenuous balance between incomprehensibility and provocativeness can be seen in certain adjustments the author has made in the construction of v. 11, both in the elaborations that were described above, but also in the vocabulary that is chosen to describe the sacrifices. The author found it too disrespectful to use conventional sacrificial terminology in this figurative sense, and therefore selected synonymous forms that did not bear the same connotations as the more technical terminology. This same reticence is seen in the author's reference to incense offerings instead of cereal and meat offerings. The author considered it improper to use the latter sacrifices in his metaphor. Another adjustment is found in the passive construction that the author uses to describe the sacrificial act. The author refrains from explicitly stating that the nations perform these sacrifices, though this conclusion is clearly implicit in the metaphor. 
supreme authority and dominion. In v. 11 the author apples this basic metaphor from v. 14 to the area of cultic life by means of certain elaborations, as was shown above. He thereby achieves a more complex metaphor in v. 11 with the meaning 'YHWH is the great king who should be worshipped as such.' Verse 11 therefore provides the basis for the demands that $\mathrm{YHWH}$ makes regarding proper cultic practice in vv. 7-10. The nations are merely used as an instrument to enhance the image of YHWH as the reigning God, an instrument that is part of the vehicle that conveys a certain message concerning the topic, i.e., YHWH, by means of metaphor.

Why, then, have readers had such difficulties in understanding this metaphor in Malachi 1:11? One answer may be found with reference to the concepts of literary (or narrative) world and ritual world. ${ }^{39}$ What is described in a text forms a world that is in a certain sense particular to that text. Thus the gospel stories are narrative worlds, and when a parable is told it constitutes the intervention of yet another narrative world, realised as a parable, i.e., an extended metaphor, by its intratextual relationship to the surrounding narrative and its world. It is the surrounding narrative that puts certain restraints on the understanding of the parables of Jesus, such as the inadequacy of understanding them literally as opposed to metaphorically.

What we find in Malachi 1:11 is somewhat similar. The narrative that surrounds v. 11 presents a particular narrative

${ }^{39}$ See W.S. Vorster, 'Meaning and Reference: The Parables of Jesus in Mark $4^{\prime}$ in B.C. Lategan and W.S. Vorster (eds.),Text and Reality. Aspects of Reference in Biblical Texts (Atlanta: Scholars Press, 1985) 60-1. Vorster speaks of a 'Narrative world'. Cf. P. Ricoeur, Hermeneutics and the Human Sciences. Essays on Language Action and Interpretation (Cambridge: CUP, 1981) 112: 'Hermeneutics can be defined no longer as an inquiry into the psychological intentions which are hidden beneath the text, but rather as the explication of the being-in-the-world displayed by the text. What is to be interpreted in the text is a proposed world which I could inhabit and in which I could project my inmost possibilities.' See also idem, Time and Narrative, Vol. 1 (Chicago: University of Chicago Press, 1984) 158-9. For a lucid explanation of Ricoeur's concept of 'narrative world', see K.J. Vanhoozer, Biblical Narrative in the Philosophy of Paul Ricoeur. A Study in Hermeneutics and Theology (Cambridge: CUP, 1990) 87-90. 
world, where priests are condemned for failing to fulfil their tasks. Then, in v. 11, another narrative world is brought in, to be understood as an elaborated metaphor through its intratextual relationship with the surrounding narrative and its world. This intratextual relationship makes a literal interpretation of v. 11 highly unlikely and favours a metaphorical interpretation instead. This second, intruding narrative world has its origin in the cultic world, 40 and is mainly presented through cultic rituals. ${ }^{41}$ The author wants his readers to enter this cultic world through his use of the standard metaphor in v. 11a, as if saying, 'YHWH is great, i.e, he deserves cultic recognition as the supreme God.' The author then elaborates on this metaphor in v. $11 \mathrm{~b}$ by using a more detailed description of the cultic world, a world well-known to him and, more importantly, to the priests he is arguing against, as if saying, 'YHWH, being the supreme God, therefore deserves the cultic recognition of all mankind.' At the same time, however, the author has forged a new metaphorical statement by the elaboration in v. 11b.42

What probably caused the subsequent misunderstandings of Malachi 1:11 was later readers' unfamiliarity with the cultic world, together with the presence of the novel metaphor in v. 11b. Since we are not able to enter into the realm of cultic life adequately, the only way for us to share its cultic world-view is through its literary remains, which are mainly found in the Psalter but also sporadically in other parts of the Old Testament such as Malachi 1:11. The lack of insight into the cultic world caused later readers to interpret Malachi 1:11 literally, a mistake that only created additional

${ }^{40}$ For this concept, see F.H. Gorman, Jr., The Ideology of Ritual. Space, Time and Status in the Priestly Theology (JSOTS 91; Sheffield: JSOT, 1990) 15.

41See J.W. Fernandez, 'The Performance of Ritual Metaphors' in J.D. Sapir and J.C. Crocker (eds.), The Social Use of Metaphor. Essays on the Anthropology of Rhetoric (Pennsylvania: University of Pennsylvania Press, 1977) 105-6.

42See Kittay, Metaphor, 299: 'Thus while habit and use can diminish the potency of a metaphor, they do not necessarily vitiate its status as metaphor. With age and use a metaphor may indeed die or become standard. However, given the proper context, the metaphor may be revived.' 
problems, as was shown above in the review of earlier interpretations. To neglect the figurative character of a metaphorical statement and instead attempt to interpret the metaphor literally cannot but create acute problems with the context that gave the statement its metaphorical character in the first place. This development is precisely what can be seen in the history of interpretation of Malachi 1:11.

One important question remains, however. Why does the author make the astonishing metaphorical statement in $\mathrm{v}$. $11 \mathrm{~b}$, instead of remaining with the more unproblematic, standard metaphor in v. 11a and c? The analysis above leads me to the conclusion that the author begins his argument against the priests in v. 11 with something they are very familiar with, since the basic metaphor 'God is king', as well as the expression 'from the rising of the sun to its setting', are well-known from the Psalter, as was demonstrated above. However, this metaphor had become a standard, or 'sleeping' metaphor that did not evoke the secondary meaning of YHWH as reigning sovereignly over all nations, but instead it functioned as a technical phrase in cultic practice. However, the author makes use of this 'sleeping' metaphor by applying it to the area where the priests had been negligent, namely cultic practices.

In doing this, the author wakens the sleeping metaphor, and he does it in two ways. First, he introduces the metaphor into a new context that itself has the potential to revitalise the metaphor by evoking the secondary meaning of the metaphor, namely, 'YHWH is supreme in the area of cultic practice.' The aim of the author was to make the priests aware of this secondary meaning of the metaphor and thereby realise their negligence. Second, the author also achieves his purpose by elaborating upon the standard metaphor in v. 11b, an elaboration that serves to waken the metaphor. It is this secondary meaning of the metaphor, secured by the elaboration in v. 11b, that the author is striving to arouse in the minds of the priests in order to make them realise the seriousness of their fault. The waking of the 'sleeping' metaphor enables the author to turn the cultic ideology, which should have been the ideology of the priests, against the priests themselves and 
thereby leave them without excuse for their negligence. What the author is hoping for is that the priests will realise that the God whose priests they are, but whose cultic worship they have neglected, is the supreme God who reigns over all, and who therefore deserves their worship. 43

\section{Conclusions}

1. Malachi 1:11 does not refer to the cultic practices of the nations as pleasing to $\mathrm{YHWH}$. Indeed, the interpretation favoured here implies instead that $\mathrm{YHWH}$ is depicted as supreme in the area of cultic life.

2. The metaphor in v. 11 is based upon the so-called root metaphor 'YHWH is king'. The cultic manifestation of this basic metaphor as it occurs in the Psalter provides the basis for the more elaborated metaphors in Malachi 1 and in particular the metaphor in v. 11.

3. Malachi 1:11 claims that $\mathrm{YHWH}$, the supreme God, is also supreme in the area of cultic life. Just as v. $14 \mathrm{~b}$ states that $\mathrm{YHWH}$ is great king over all nations-a statement which could never be taken literally-so YHWH is also brought sacrifices by all people, which likewise could never be taken literally. The solution is that these statements refer metaphorically to the cultic supremacy of YHWH. Given his cultic supremacy, he deserves cultic recognition in the form of sacrifices from his chosen people, presented through their cultic functionaries, the priests.

4. A review of earlier interpretations reveals a lack of sensitivity to figurative language, especially metaphor, when it is used to describe various aspects of $\mathrm{YHWH}$. The alternative of transposing the reference of statements in v. 11 to the future is one common misapprehension resulting from such a failure to recognise metaphorical language.

5. The various misunderstandings of Malachi 1:11 are due to a lack of insight into the 'cultic world', which has been actualised

${ }^{43}$ For a similar line of reasoning, see J.L. Berquist, "The Social Setting of Malachi', BTB 19 (1989) 124: 'the priests are called to be accountable to their own tradition.' 
in the form of a 'narrative world', which the reader enters through a metaphor. The reason we are still able to enter this cultic world is because the relationship between the metaphor and its context forces us away from a literal reading in the direction of metaphorical understanding.

6. The author starts with a standard metaphor with which priests had become intimately familiar through its use in cultic contexts, where it had, however, lost its secondary meaning and been relegated to the status of a technical phrase. He then elaborates upon this metaphor to waken its secondary meaning of YHWH's cultic supremacy. The author's aim was to make the priests acknowledge the secondary meaning as inherent to their own ideology-not a mere product of the author's own imagination-thereby exposing their behaviour as clearly inexcusable. 